\title{
„Amerykanin, Rusek i Polak... " Kawał polityczny w PRL-u w kontekście międzynarodowym
}

Piotr Michałowski 
nAPNS Seria XIV 2008

\section{Piotr Michałowski}

\section{„Amerykanin, Rusek i Polak...” Kawał polityczny w PRL-u w kontekście międzynarodowym}

$\mathrm{P}$ odejmując ten temat, znalazłem się w sytuacji co najmniej paradoksalnej: albo tragicznej, albo po prostu komicznej. Zmusza ona bowiem, by opowiadać stare kawały, i to nie tylko, jeśli chodzi o egzemplifikację, bo dotyczy to także cytowania cudzych refleksji z dość już bogatej teorii i historii humoru politycznego, nagromadzonej przez ostatnie dwudziestolecie. Dezaktualizacja podawanych tu przykładów autora z jednej strony cieszy jako obywatela RP, z drugiej martwi jako miłośnika dowcipu, który, porzuciwszy rolę dawnego użytkownika, musi przeobrazić się w historyka formy dziś już prawie martwej. Dyskomfort zwiększa ponadto konieczność dokonania zapisu tego, co kiedyś żyło w mowie. Pogląd, że pismo jest „śmiercią” żywego słowa, znajduje bowiem największe uzasadnienie właśnie w przypadku tego, co potocznie nazywa się „kawałem”.

\section{Gatunek i nazwa (zakres terminu)}

Jako były użytkownik — zarówno słuchacz, jak i opowiadacz, pamiętający obyczaje tamtej epoki - pozostanę wierny funkcjonującej wówczas nazwie formy: „kawał”. Opowiadano bowiem wyłącznie właśnie „kawały”, a nie żadne „dowcipy”, jak sugeruje większość późniejszych opracowań. Przyznam więc rację pierwszemu polskiemu teoretykowi tego zjawiska, Zbigniewowi Raszewskiemu, którego naukowy rekonesans powstał jeszcze w epoce Gomułki, w roku 1966, choć w postaci oficjalnego druku pojawił się dopiero ćwierć wieku później¹. Wybitny teatrolog, a okazjonalnie pionier

1 Zob. Z. Raszewski, Wstęp do teorii kawału, „Polska Sztuka Ludowa”, 1990, nr 2, s. 3-9. 
teorii omawianego gatunku, słusznie zauważył, iż nie można utożsamiać „kawału” ani z „dowcipem” (który cechuje również inne formy wypowiedzi), ani z „anegdotą" (która zakłada prawdziwość opowiadanego zdarzenia), ani też wiązać go z tradycją fraszki (gdyż ta mieści się w literaturze pisanej, a nie ustnej)².

Stosując quasi-gatunkowy termin „kawał polityczny” jako powszechnie przyjęty, zwykle nie dostrzegamy jego — dalekiej od precyzji — umowności. Obejmuje on przecież nie tylko dowcipy o politykach i polityce, ale ma o wiele szerszy zakres tematyczny, ogarniając niemal wszystkie sfery życia, które w jakimś stopniu były uwikłane w sytuację polityczną PRL-u lub wprost wynikały z decyzji monopolistycznej władzy. Tak szerokie ujęcie podpowiada bogaty materiał, który pod tą nazwą albo już funkcjonuje, albo da się umieścić. Wiadomo bowiem, że jedynie w ustroju o znamionach totalitarnych to, co dla cudzoziemca z Zachodu (dla którego warunki życia w gospodarce wolnorynkowej są oczywistością) byłoby niezrozumiałe, zwłaszcza żarty o podwyżkach cen mięsa, w Polsce miało wyraźny wydźwięk „polityczny”.

Po drugie, „polityczność” charakteryzuje nie tylko tematykę, ale również obieg; dotyczy bowiem zarówno opisu ,upolitycznionych" realiów życia w PRL-u, jak i granic legalnego kolportażu. Wyznacza więc wąski zakres wolności słowa. Znajdowało to zresztą odbicie w języku władzy i potocznym użyciu przymiotnika „polityczny”: służył on za ostrzeżenie dla obywatela wykraczającego poza przypisaną mu rolę i naruszającego partyjny monopol na politykę (dogmat o „kierowniczej roli Partii”); oznaczało zatem strefę niebezpieczeństwa. "Wasze postulaty mają charakter polityczny" - tak przemawiała władza do strajkujących i określenie to brzmiało równie groźnie jak oskarżenie o zdradę i rewizjonizm. W tej sytuacji kawal krytykujący socjalistyczną rzeczywistość (choćby pośrednio) nie mógł liczyć na rozpowszechnianie oficjalne i jawne - wyjąwszy przypadki graniczne, jakimi były niektóre kabarety, licencjonowane przez władzę na prawach wentyla bezpieczeństwa, albo incydenty „przemytu” za cichym przyzwoleniem decydentów, a wreszcie ryzykowne akty naruszenia umowy z cenzorem. „Kawał polityczny” znaczy więc również tyle, co „funkcjonujący poza cenzurą”, czyli „nielegalny”3, co ogranicza zakres jego rozpowszechniania do obiegu ustnego, rzadziej również do wtórnie drugoobiegowego i emigracyjnego ${ }^{4}$. Wojciech

\footnotetext{
2 Zob. ibidem, s. 3.

3 Kryterium to bywa nawet przyjmowane za nadrzędne - co sygnalizuje choćby tytuł obszernej dwutomowej antologii: Dowcip surowo wzbroniony. Antologia dowcipu politycznego (red. V. Syguła-Gregorowicz, M. Waloch, t. 1-2, Torun 1990-1991).

${ }^{4}$ Warto wspomnieć o tych obiegach (raczej jako wtórnych), choćby dla dwóch przykładów. Czasopiśmiennictwo podziemne w stanie wojennym dorobiło się pisma satyrycznego pod nośnym tytułem „Jaruzela”, a paryska „Kultura” prowadziła rubrykę, w której zamieszczała aktualne (choć z pewnym poślizgiem) kawały polityczne. Oczywiście publikacja w tym drugim przypadku służyć mogła raczej za cenną dokumentację tego, co ulotne, niż rozpowszechnianiu, z którym wypróbowany obieg ludowy radził sobie znacznie lepiej i bez pomocy źródeł drukowanych. Omówienie sytuacji kawału
} 
Łysiak trafnie pisze o „folklorze politycznym”, jakkolwiek warto zauważyć, że w popularnym stosowaniu tego terminu łatwo o pomyłkę, gdyż takie określenie obejmuje nie tylko kawały o polityce, ale i dowcipy samych polityków - wygłaszane z trybun aforyzmy i bon moty, koncepty retoryczne, także mimowolne, a więc śmieszne nieporadności, omyłki, a zwlaszcza wielkie gafy i wpadki, chętnie rozpowszechniane potem przez przeciwników jako narzędzie walki politycznej, stanowiące pożywkę dla powstających później anegdot. Wypowiedzi polityków niekiedy nawet stanowią ready-mades - które wystarczy zacytować w niezmienionej postaci i bez komentarza satyrycznego ${ }^{6}$.

Po trzecie, „polityczny” można również rozumieć - co już wydaje się ujęciem ryzykownym - w ścisłym znaczeniu tego przymiotnika, to znaczy jako będący narzędziem uprawiania polityki i walki o władzę. Chodziłoby więc o aspekt instrumentalny i performatywny: oddziaływanie dowcipem, rzecz jasna, raczej nie na ośrodki władzy, przeciw którym jest wymierzony, ale na społeczeństwo, by je podnosić na duchu, a także budzić ducha oporu. To właśnie kawał w jakimś stopniu kształtowal - a przynajmniej wyznaczal jej zakres - jakąś, może największą w całym obozie socjalistycznym, opozycyjną wspólnotę komunikacyjną, swoistą „wspólnotę śmiechu”, na pewno znacznie liczniejszą od grona czytelników nielegalnie kolportowanej „bibuly”. Nie twierdzę, że na modłę romantyczną przygotowywal on powstanie narodowowyzwoleńcze lub antykomunistyczną rewolucję, ale może w pozytywistyczny sposób „krzepił serca” i ułatwiał przetrwanie. Trudno jednak lekceważyć mniejszościowe opinie przeciwne, na przykład, że humor ten działał na odwrót - neutralizował społeczne nastroje i umacniał mentalność niewolnika. Wśród takich poglądów pojawiają się jeszcze skrajne, wedle których kawał polityczny był nie tylko rozpowszechniany odgórnie, ale wręcz powstawał w ośrodkach władzy, która — na długo przed procederem Chucka Norrisa — sama wymyślała żarty o sobie.

w stanie wojennym znajdziemy w artykule Wojciecha Polaka Humor i satyra niezależna w Polsce $w$ latach 1981-1989 („Czasy Nowożytne” 2002, t. 13, s. 151-175).

${ }^{5}$ W. Łysiak, Oblicza folkloru - folklor polityczny, „Polska Sztuka Ludowa” 1990, nr 2, s. 15; idem, Folklor polityczny w PRL, Poznań 1998, s. 7.

${ }_{6}$ Np. Pan Prezydent powiedziat (czyli 120 nieprzyzwoitych anegdot i przypowiastek o Lechu Watesie), red. W. J. Huziak, Warszawa 1995. Przykładem efektu obróbki zapisu dokumentalnego przez groteskowy montaż był z kolei cykliczny program Jacka Fedorowicza Dzientik telewizyjny. W tym przypadku humor powstaje dopiero w zestawieniu innej albo dodaniu zmyślonej wypowiedzi, komentującej sytuację rzeczywistą, utrwalona przez kamerę. Pisze o tym Slawomir Kmiecik (Wolne żarty! Humor i polityka, czyli rzecz o polskim doucipie politycznym, Warszawa 1998, s. 25-43). W czasach PRL-u było to jednak niemożliwe wobec państwowego monopolu na media, które poddane najuważniejszej cenzurze, rozpowszechniać gaf polityków nie mogły, a ich przeoczenie przez redaktorów i dopuszczenie na wizję było błędem równym niemal zdradzie stanu. 


\section{Mowa i zapis (obieg folklorystyczny)}

Jeśli wierzyć Mickiewiczowskiemu Wajdelocie, właśnie obieg ustny daje gwarancję przetrwania słowa, ale zarazem niesie ryzyko zapomnienia. Zwłaszcza wtedy, kiedy tekst straci aktualność, domaga się etnograficznego zapisu, co postulował już Raszewski, stwierdzając jeszcze w 1990 roku dotkliwy brak dokumentacji, zarówno w postaci antologii, jak i opracowań 7 . Proces kodyfikowania humoru na wielką skalę przyniosły dopiero lata dziewięćdziesiąte XX wieku, kiedy to lawinowo zaczęły się ukazywać mniejsze i większe antologie, a także dostępne głównie w kioskach całe serie broszur oraz czasopisma będące zbiorami dowcipów na wszystkie możliwe tematy - począwszy od chirurgów, a kończąc na teściowej; kawałów lepszych i gorszych, starych i świeżo wymyślanych, często przez osoby biorące udział w konkursach ${ }^{8}$. Masowa produkcja kawałów drukowanych stała się jednak zjawiskiem odrębnym, i choć dowcip o politykach był w niej silnie reprezentowany, w warunkach demokratycznych oznaczal już coś zupelnie innego - walkę między zmiennie rządzącymi ekipami i konkurencyjnymi partiami. Afery gospodarcze, korupcja, pijaństwo posłów, kuriozalne wnioski sejmowe i projekty rządowe - wszystko to wykorzystuje się głównie w walce politycznej do zdyskredytowania przeciwnika przez ośmieszenie. Są również dowcipy służące walce ideologicznej, wymierzone w pewne grupy społeczne, a więc mające podłoże w nietolerancji światopoglądowej — zarówno antylewicowe, jak antyprawicowe, antysemickie i antyklerykalne, antyliberalne i antykatolickie.

Zanim rozważę cele humoru politycznego, jego oddziaływanie i specyfikę, którą nadaje mu obieg ludowy, dokonam przeglądu tematycznego i gatunkowego a posłużę się przykładami zaczerpniętymi ze zbioru Zakazany wic ${ }^{9}$, który, choć dąży do kompletności, stanowi zaledwie mini-antologię kawału politycznego. Dzieli się na cztery części, odpowiadające epokom i przywódcom PRL-u, przezwanym na modłę dynastycznych monarchów zrymowanymi przydomkami: Bierut (Bolesław Okrutny), Gomułka (Władysław Bałamutny), Gierek (Edward Hojny) i Jaruzelski (Wojciech Zbrojny). Rozdziały wyznaczone są więc przez lata cezury historii PRL-u: 1945, 1956, 1970 i 1980, co wydaje się pomysłem trafnym, jakkolwiek trzeba zastrzec, że zdarzają się dowcipy „wędrowne”, przechodzące z epoki do epoki. Okresy te róż-

\footnotetext{
7 Zob. Z. Raszewski, Wstęp do teorii kawatu, op. cit., s. 3.

${ }^{8}$ Wśród periodycznych wydawnictw tego typu wymienić można wydawane przez Stefana Sandurskiego miesięczniki: „Dobry Humor”, „103 Najlepsze Dowcipy”, „Dowcip Miesiąca”, „Super Dowcipy” i „Humor - Rysunki / Twój Dobry Humor”, zamieszczający najwięcej dowcipów politycznych oraz wydawane przez Andrzeja Podulkę: miesięcznik „Świeże Dowcipy” i dwumiesięczniki „Ale Jaja”, "Coś z dowcipami”. Ponadto warto wymienić: Konuniada. Humor polityczny, rys. J. Fudala, Kraków 1990, 501 dowcipów politycznych, Wałbrzych 1993.

${ }^{9}$ Zakazany wic, czyli polski dowcip polityczny 1944-1990, zebrał, wybral i oprac. W. Tocki, Łomża 1990. Dowcipy cytowane z tego źródła oznaczam w pracy skrótem: ZW.
} 
nią się także malejącym ryzykiem rozpowszechniania kawału politycznego: za Bieruta było ono najwyższe i zagrożone największymi represjami, w stanie wojennym, po okresie 16-miesięcznej dwuwładzy, gdy wszyscy oficjalnie zdążyli się dowiedzieć nawet z mediów, że „król jest nagi”, ustny kolportaż dowcipów odbywał się już masowo i niemal jawnie.

Twórca antologii we wstępie tak charakteryzuje cel i genezę swego edytorskiego przedsięwzięcia:

Jeden z autorów wydawnictwa „Przedświt” ogłosił swego czasu projekt budowy pomnika, poświęconego dowcipowi politycznemu. Uzasadnienie: „celność anegdoty obnaża niedorzeczność wszystkich wykrętów propagandowych. Dowcip ten przetrwał najcięższe okresy, wytrwał, rozrósł się w całe serie i można dziś w oparciu o niego studiować całą historię władzy $[\ldots]$ i socjalizmu".

Niech zabrzmi to jak żart, ale pierwszym w Polsce takim pomnikiem dowcipu spoza oficjalnego obiegu, zakazanego, za który, bywało, niezmiernie gniewała się władza, a jej „przedłużone ramię” wybijało go obywatelom z głów pałkami i wyrokami „za zbrodnię zelżonego majestatu” jest [niniejszy - dop. P. M.] zbiorek [...]. Powstał w całości z „podań ludu”: na apel Łomżyńskiego Społecznego Tygodnika „Kontakty” w czasie zaledwie miesiąca z całego kraju (a także USA, Belgii i RFN) napłynęło ponad 1500 listów, zawierających kilka tysięcy wiców, anegdot, „trefnych” fraszek i wierszyków. Ludzie, niezależnie od wieku, płci, wykształcenia, majątku, poglądów chwytali za pióro, odświeżali pamięć i spisywali wice $[\ldots]^{10}$.

Warto zauważyć, że wiele kawałów ocalało również dzięki publikacji w instruktażach cenzorskich, a więc — „bezpiecznie” rozśmieszony cenzor konfiskowal to, co mogło „niebezpiecznie” rozśmieszyć obywatela ${ }^{11}$.

Pamiętajmy jeszcze o tym, że bohaterami niektórych żartów są osoby nadal żyjące. O zniesławienie mogą być oskarżeni ci, którzy rozpowszechniają obraźliwe kawały, ponieważ anonimowego autora oskarżyć nie sposób. Twórcy przywołanej antologii jako pierwsi podjęli więc największe ryzyko prawne, natomiast autorzy opracowań „kawałologicznych", idący przetartym przez nich szlakiem, mogli już swobodnie cytować ze źródeł drukowanych, nie ponosząc za to żadnej odpowiedzialności'12.

${ }^{10}$ W. Tocki, Dobry żart..., [wstęp do:] Zakazany wic, op. cit., s. 3-4.

${ }^{11}$ S. Kmiecik, Wolne żarty!..., op. cit., s. 48-49.

12 Wyjaśnia to Sławomir Kmiecik w rozmowie z prawnikami: Aleksandrem Bentkowskim i Jackiem Taylorem (ibidem, s. 115-116). 


\section{Polityka i codzienność (zakres tematyczny)}

Jak już wspomnialem, zakres tematyczny kawału politycznego wydaje się nieograniczony, gdyż mogą się w nim pojawić właściwie wszystkie motywy związane z realiami życia w PRL-u. Są również dowcipy „okolicznościowe” — jako reakcje na wydarzenia i komentarze do nich: na przykład serie o wypadkach polskiego Marca 1968 roku $^{13} \mathrm{czy}$ o interwencji w Czechosłowacji. Są dowcipy o kryzysie gospodarczym i tzw. „reformie gospodarczej" z lat osiemdziesiątych, o stanie wojennym, Okrągłym Stole, katastrofie w Czernobylu, zabójstwie księdza Popiełuszki. Są jednak stałe tematy preferowane, których „opracowanie humorystyczne" stało się potrzebą pilniejszą od innych, a chodzi o nasilające się zjawiska społeczne, konkretne decyzje władz, wydarzenia uliczne, strajki. Co jednak należy do tematów najczęstszych? Oto ich dość długa lista:

— charakterystyka przywódców PRL-u: ich głupota, język propagandy, kult jednostki;

- charakterystyka aparatu władzy i jego funkcjonariuszy: przemoc, podejrzliwość, inwigilacja, ale także słabości: głupota, fanatyzm, chciwość, chwiejność ideologiczna i koniunkturalizm;

- polityka gospodarcza: „planowa” i rabunkowa (handel z ZSRR), braki w zaopatrzeniu w mięso, podwyżki cen, bieda i totalna niewydolność systemu;

- polityka wewnętrzna: brak demokracji i wolności słowa, zasada nomenklatury partyjnej w obsadzaniu kierowniczych stanowisk, kariery robione dzięki poprawności ideologicznej, a nie wykształceniu, konfliktowe relacje państwo-Kościół, niskie place, strajki;

- polityka zagraniczna: serwilizm władz PRL-u w stosunkach z ZSRR, niesuwerenność państwa, „bratnia pomoc” w tlumieniu powstań w bloku wschodnim i innych krajach, radziecki imperializm.

Na pewno w PRL-u humor zdominowała satyra, natomiast dowcip abstrakcyjny, absurdalny, językowy oraz inne jego odmiany „bezinteresowne” nie miały większej racji bytu i stanowiły zaledwie niszę, uznawane były nawet za pewną dewiację, i wprawdzie pobudzały do śmiechu, lecz jednocześnie wywoływały pewne zażenowanie z powodu braku oparcia w rzeczywistości społeczno-politycznej, uznawanej za temat niemal obowiązkowy. Sytuacja ta wynikała tyleż z obywatelskiego zaangażowania (wyznaczonego jeszcze romantycznym etosem polskiej literatury), co trwałego przypisania humorowi funkcji agresji: dobry dowcip musiał być albo „przeciw”, albo w ogóle go

${ }_{13}$ Te doczekały się już opracowań, np.: I. Einhorn, Marzec'68 $w$ anegdocie, „Nauki Humanistyczne” 1998, nr 4, s. 265-268. 
nie było (jako opowiastki „o niczym”). Wyjątek stanowią pewne autonomiczne strefy humoru erotycznego, obscenicznego i skatologicznego.

\section{Figury i pionki (bohaterowie kawałów)}

Ponieważ kawał polityczny opiera się na schemacie czarno-białym i na kontraście satyrycznym, występują w nim bohaterowie jednoznacznie negatywni obok pozytywnych, ale tym pierwszym, jako będącym obiektem kpiny, przypada rola główna.

Prócz wymienionych przywódców, których nazwiska wyznaczają kolejne epoki PRL-u: Bieruta, Gomułki, Gierka i Jaruzelskiego, także inne postacie wpisują się na długą listę bohaterów negatywnych jako funkcjonariusze systemu komunistycznego. Są wśród nich politycy polscy i radzieccy, a także przywódcy „bratnich” krajów bloku wschodniego: Babiuch, Beria, Berman, Bułganin, Ceausescu, Chruszczow, Cyrankiewicz, Czernienko, Dzierżyński, Glazur, Gorbaczow (sic!), Grudzień, Hermaszewski (choć kosmonauta, ale też członek WRON, gdzie pełnił raczej funkcję dekoracyjną), Jabłoński, Jaroszewicz, Kaganowicz, Kłonica, Kosygin, Krasiński, Krupska, Lenin, gen. Malinowski, Mao-Tse-Tung, Messner, Mikojan, Minc, Motyka, Obodowski, Ochab, Pyka, Radkiewicz, Rakowski, Rokossowski, Siwak, Stalin, Szydlak, Urban, Żabiński, Żandarowski. Znalazły się więc tutaj nazwiska osób żyjących obok nieżyjących. Figury i pionki. Alfabetyczne wyliczenie miesza postacie największych przywódców politycznych ze skromnymi funkcjonariuszami systemu, ale w światach przedstawionych anegdot ich ranga odpowiada już obsadzie: w rolach głównych anegdotycznych fabuł bądź jako statystów. Niektórzy grają wyłącznie epizody lub służą jedynie do wyeksponowania postaci pierwszoplanowych. Jedni pojawiają się samotnie, inni z rodzinami lub w obstawie podwładnych.

$\mathrm{Na}$ przeciwnym biegunie sytuują się „bohaterowie pozytywni”, choć określenie to wydaje się nieadekwatne, gdyż ich obecność nie jest uzasadniona potrzebą dokonania apoteozy; służą oni tylko za kontrastowy punkt odniesienia. Presupozycją dowcipu politycznego jest bowiem założenie, że słuchacz sytuuje się po stronie opozycji wobec władzy, toteż milcząco podziela racje kolportera (opowiadacza) i w d o m yśle akceptuje całą szeroką reprezentację opozycji demokratycznej: Bujak, Dubczek, kardynał Glemp, Gwiazda, Jan Paweł II, Kuroń, Mazowiecki, ks. Popiełuszko, Reagan, Wałęsa. Trudniej natomiast określić ambiwalentną pozycję przywódców zachodnioniemieckich: Adenauera i Kohla, których wizerunki w świadomości powszechnej prawdopodobnie jeszcze nie wyzbyły się piętna rewizjonistycznego zagrożenia. Antyniemieckość, choć przykrojona na użytek walki systemów (a więc nie obejmująca „bratniej” NRD), stanowiła bowiem ten wątek propagandy PRL-u, który wciąż przemawiał do innych obszarów świadomości politycznej i historycznej obywatela niz krytyka kapitalizmu.

Prócz bohaterów indywidualnych pojawiają się zbiorowi. Negatywni to rządy, organizacje, instytucje razem $z$ ich funkcjonariuszami. Są więc anonimowi urzędnicy, 
aktywiści i agitatorzy, oficerowie i żołnierze, a zwłaszcza ubecy i milicjanci, ORMO, ZOMO, PZPR, WRON i SdRP, Wojskowe Grupy Operacyjne i branżowe związki zawodowe. Jest RWPG i Układ Warszawski, „Trybuna Ludu” i Dziennik Telewizyjny DTV. Z kolei bohaterowie zbiorowi pozytywni to: chłopi, robotnicy (zwłaszcza górnicy i stoczniowcy), inteligenci, studenci, czyli obywatele z różnych „klas społecznych”, NSZZ „Solidarność” - ale także grupy, które rozpoznajemy jako imigrantów pochodzących $z$ wyspecjalizowanych dowcipów na inne tematy, a są wśród nich: więźniowie (nie tylko polityczni), górale, księża i Żydzi (ze szmoncesów), rzadziej szpiedzy i agenci CIA. Znajdują się wśród nich także wariaci, którzy jako jedyni kompromitują system komunistyczny na dwa sposoby: albo demaskując wprost jego nienormalność, albo przekornie go popierając; podobną rolę demaskatora odgrywa Jasio, bohater popularnych dowcipów o szkole. Pojawia się wreszcie Pan Bóg jako arbiter, najwyższa doczesna instancja odwoławcza lub sędzia ostateczny w zaświatach, który jednak nie zawsze okazuje się siłą zdolną pokonać komunizm.

\section{Dialog i puenta (schematy konstrukcyjne)}

Anatomię kawału określa ogólne prawo „zgodnej niezgodności” (concors discordia) i na nim opierają się wszystkie odmiany konstrukcyjne tego gatunku. Według Victora Raskina każdy dowcip musi spełniać warunek: zgodności (choćby częściowej) z dwoma niezgodnymi ze sobą skryptami (strukturami poznawczymi) ${ }^{14}$. Budowa kawału politycznego zasadniczo nie odbiega od poetyki humoru na inne tematy. Rządzi więc nim retoryka antytezy i hiperboli. Można wyróżnić kilka podstawowych form kompozycyjnych.

A. Pytanie - odpowiedź:

- Czy Monako może być państwem komunistycznym?

— Nie, ponieważ byłoby to zbyt duże nieszczęście na tak mały kraj [ZW, s. 7].

Antologia Tockiego niestety całkowicie pomija jedną z najpopularniejszych serii reprezentujących właśnie ten typ kawału, a więc „Pytań do Radia Erewań”. Dostępne są one w innych antologiach ${ }^{15}$.

B. Parodia

Dotyczy przemówień, doniesień prasowych (tu mieści się znana seria o agencji TASS), wreszcie umów gospodarczych — jak ta, oparta nie tyle na błędzie logicznym, ile na figurze pozornego chiazmu:

${ }^{14}$ Cyt. za: S. Kmiecik, Wolne $\dot{z} a r t y !$.. op. cit., s. 96.

${ }^{15}$ Zwłaszcza osobny zbiór Na erewańskiej fali (Warszawa 1990). 
Umowa handlowa zawarta między Polską a Związkiem Radzieckim:

1. Związek Radziecki będzie otrzymywał od Polski połowę wydobytego węgla.

2. W zamian za to Polska będzie wysyłać do Związku Radzieckiego połowę produkcji cukru i wieprzowiny [ZW, s. 13].

Te bliskie są niekiedy innej formie — grze logicznej:

Partia jest konsekwentna. Gdy partia mówi, że nie da — to nie da! Gdy partia mówi, że da - to mówi [ZW, s. 63].

C. Gry slów

Są to dowcipy lingwistyczne, na przykład oparte na kalamburze, odnajdującym niespodziewany sens jakiegoś słowa, skrótu lub nazwiska:

Związkowi Radzieckiemu przybyły 2 nowe stany: Afganistan i stan wojenny w Polsce [ZW, s. 84].

- Wymień wyznania w Polsce.

- Prowiesławie, gierkokatowicyzm i 30 milionów protestantów [ZW, s. 59].

Jak widać w tym przykładzie, wskazane formy mogą się nakładać na siebie i kompilować. W tym przypadku występuje schemat „pytanie-odpowiedź” i gra słów zarazem. Oto jeszcze jeden przykład:

— Czym się różnią błędy kapitalizmu od błędów socjalizmu?

— Kapitalizm ma blędy socjalne, a socjalizm kapitalne [ZW, s. 108].

Albo ten, należący chyba do najcelniejszych:

— Jaka jest różnica między demokracją a demokracją socjalistyczną?

— Taka, jak między krzesłem a krzesłem elektrycznym [ZW, s. 77].

Niektóre kawały typu „pytanie-odpowiedź” wydają się najbardziej nastawione edukacyjnie i wykorzystują technikę katechizmu. Tworzą jednak swoisty katechizm rewolucji, gdyż zamiast utrwalać dogmaty, uświadamiają paradoksy rzeczywistości, „otwierają oczy”, wskazując na nienormalność zjawisk, z którymi zdążyliśmy się już oswoić na tyle, by je uznać za naturalne.

\section{Scenki dialogowe}

Raszewski uznaje właśnie rozmowę za genezę kawału, jego najważniejszy składnik i zarazem główny podgatunek (obok odmiany, jaką jest z a ga d ka). Zwraca także uwagę na to, co różni tę rozmowę od dialogu w dramacie: na zbytnią jednostronność (którą 
zresztą zarzucano również dramatom Sławomira Mrożka). Według badacza podstawą tego rodzaju kawałów jest więc raczej satyra niż dramat ${ }^{16}$.

Gazeciarz do żołnierza sowieckiego:

— Towariszcz! Kup gazetę!

— Ja nie kuraszczy — odpowiada żołnierz [ZW, s. 8].

Dialog może obejmować większą liczbę replik, ale jego istota sprowadza się zwykle do konfrontacji odmiennych postaw, poglądów lub kontrastowej interpretacji rzeczywistości, przy czym puenta należy zwykle do reprezentanta opozycji, gdyż po jego stronie sytuuje się racja, którą w założeniu opowiadacza podziela odbiorca kawału.

\section{E. Anegdoty narracyjne}

Historyjki z życia przedstawicieli władzy (zarówno prawdziwe, jak zmyślone) lub obywateli zawierają również zazwyczaj dialog albo przytoczenie pojedynczej wypowiedzi bohatera w pozycji puenty:

Minister kultury od rana jeździ samochodem służbowym od kościoła do kościoła. Zainteresowało to funkcjonariuszy UB, więc zatrzymali ministra, zarzucając mu kompromitację partii i rządu.

- Towarzysze darujcie, ale dostałem zaproszenie na Wesele Wyspiańskiego, lecz nie podali, w którym kościele się odbędzie [ZW, s. 30].

Czasem w świecie przedstawionym pojawiają się schematy i postacie z baśni (np. o złotej rybce), duchy postaci historycznych (Piłsudski, Lenin), bohaterowie literaccy i filmowi. Kawał czerpie z różnych konwencji literackich i wzorców: realizmu i fantastyki, groteski, absurdu i czarnego humoru. Pojawiają się więc również motywy okrucieństwa i makabry:

Szczyt marzeń Polaków lat siedemdziesiątych: wdowa po Jaroszewiczu mówi do żony konającego Jabłońskiego, że Gierek zginal jadąc na pogrzeb Breżniewa [ZW, s. 71].

Przechodzień do ZOMO-wca:

- Gdzie pan kupil pomarańcze?

- W sklepie za rogiem.

- A duża kolejka?

— Nie, tak na jeden magazynek [ZW, s. 89].

${ }^{16}$ Zob. Z. Raszewski, Wstęp do teorii kawału, op. cit., s. 5. 
Istnieją wreszcie dowcipy eschatologiczne, których akcja toczy się po końcu świata, w raju albo w niebie. Są także dowcipy katastroficzne:

Przed gwiezdnymi wojnami prezydent USA kazal się zamrozić. Ciało jego miało być przechowywane, dopóki nie skończy się wojna. Po działaniach wojennych odmrożono go, wstał osowiały i pyta:

- Jak było?

- Jak to na wojnie - odpowiada generał.

- No, dobrze. Dajcie mi gumę do żucia, dawno nie żułem, a w ogóle to guma jeszcze jest? - pyta prezydent.

- Jest - odpowiada general.

- A ile kosztuje? - pyta prezydent.

— Rubel dwadzieścia [ZW, s. 78-79].

F. Gradacje

Chodzi o struktury narracyjne lub dialogowe, oparte na stopniowaniu, najczęściej potrójnym, przy czym ostatnia z sytuacji nabiera cech absurdu:

W ZSRR ogłoszono konkurs na najlepszy zegar z kukułką. Trzecie miejsce zajął zegar, z którego co godzinę wyskakiwała kukułka i wołała: „Lenin, Lenin". Drugie miejsce dostał zegar, z którego co pół godziny wyskakiwała kukułka i wołała: „Lenin”. Pierwsze miejsce przyznano zegarowi, z którego co kwadrans wyskakiwal Lenin i wołał: „Ku-ku-ku-ku” [ZW, s. 17].

Odmianą takich dowcipów opartych na gradacji są anegdoty o tematyce „międzynarodowej".

\section{Polak i inni (kawały „międzynarodowe”)}

„Amerykanin, Rusek i Polak...” to jeden z bardziej reprezentatywnych schematów sytuacyjnych polskiego dowcipu politycznego, stanowiący zarazem jedną z najpopularniejszych i chyba najdłuższych serii anegdot o tematyce „międzynarodowej”. Seria ta, jak podaje Wojciech Łysiak, narodziła się pod koniec lat pięćdziesiątych $\mathrm{XX}$ wieku ${ }^{17}$. Tytułowa trójka to przedstawiciele konfliktowych systemów społeczno-politycznych, zarazem uosabiający zdecydowanie odmienne charaktery narodowe - rozpięte między kapitalizmem a socjalizmem, Zachodem a Wschodem, często z rozdartym między te dwie opcje Polakiem pośrodku. Kawały te zwykle ujawniają kontrastowe postawy, czasem ułożone w gradację, przy czym zwykle „ostatnie słowo”

${ }^{17}$ Zob. W. Eysiak, Oblicza folkloru - folklor polityczny, op. cit., s. 17. 
należy właśnie do Polaka, który puentuje sytuację swym stanowiskiem lub jakimś czynem ekstremalnym, wykazując największą przebiegłość, determinację, głupotę albo szaleństwo. Są to zatem często dowcipy o samych Polakach, o ich mentalności, utrwalające stereotyp brawurowego wariata albo megalomanię narodową, a międzynarodowe tło służy jedynie do wyeksponowania kontrastu $\mathrm{z}$ jakąś nie zdefiniowaną „normą”. Kawały te nie zawsze opisują układ geopolityczny, niekiedy dotyczą tylko różnic kulturowych (mentalnych i obyczajowych), prezentując karykaturę charakteru narodowego.

Seria ta ma kilka rozgałęzień i odmian z różną obsadą bohaterów, w których zamiast Amerykanina występuje na przykład Niemiec lub Francuz, natomiast pewne postacie, a zwłaszcza Polak, są w polskim dowcipie raczej niewymienne, choć z jednym wyjątkiem: jeśli ktoś słowem lub czynem pobije Polaka, może nim być tylko Rosjanin:

Agencja Badania Opinii Publicznej przeprowadza ankietę na temat braku mięsa. Co to znaczy „brak”? — zapytuje Amerykanin. Co to jest „mięso”? — dziwi się Polak. Co to jest „ankieta”? — pyta Rosjanin ${ }^{18}$.

Oto przykład innej konfiguracji postaci w parafrazie legendy genetycznej o Lechu, Czechu i Rusie:

Szedł Czech, Lech i Rus. Szli, szli aż doszli nad Wełtawę. Tam Czech postanowil, iż zostanie. Dalej poszli Lech i Rus. Długo szli, aż doszli nad Wisłę. Tutaj Lech zdecydował się osiedlić. Dalej poszedl tylko Rus. I chodzi tak do tej pory. Ostatni raz widziano go w Afganistanie [ZW, s. 108].

Osobą trzecią może być również Żyd - jako przedstawiciel nacji najprzebieglejszej, który kpi sobie z podziałów geopolitycznych świata. Na przyklad ma trzech synów: pierwszego w Moskwie, który buduje tam socjalizm, drugiego w Warszawie, który robi to samo; trzeci jest w Tel-Awiwie. Żyd zapytany, czy ten ostatni także buduje socjalizm, odpowiada oburzony:

— No coś ty? We własnym kraju? [ZW, s. 48].

Międzynarodowy skład bohaterów (i zwykle zarazem interlokutorów) jest zmienny:

Wszystkie nacje mają pociąg do hazardu: pięciu młodych Amerykanów siada do samochodów i robią wyścigi; jeden samochód ma niesprawne hamulce, ale nie wiadomo który. Pięciu Francuzów idzie do domu pu- 
blicznego; jedna z pensjonariuszek ma syfilisa, lecz nie wiadomo która. Pięciu Polaków siada przy litrze czystej i opowiada dowcipy polityczne. Jeden $z$ nich jest konfidentem, tylko nie wiadomo który [ZW, s. 24].

Są dowcipy, w których spotyka się tylko Rosjanin z Polakiem albo Amerykanin z Rosjaninem. W kawale bez udziału Polaków, puenta przypada oczywiście Rosjaninowi. Niekiedy zamiast osób pojawiają się trzy waluty: dolar, rubel i złoty, z których pierwsza opiera się na ropie, druga na złocie, a trzecia na „cynie (społecnym)”. Niekiedy zamiast synekdochy z przedstawicielami narodów pojawiają się całe narody lub kraje, np. Ameryka — Francja — Polska — ZSRR:

Naukowcy amerykańscy dokonali strasznego odkrycia: za trzy dni nastąpi koniec świata. Postanowili sprawdzić, jak zareagują na tę wiadomość poszczególne narody. Lecą nad Francją, a tam wszyscy uprawiają miłość. Przelatują nad Polską, wszyscy piją na umór. Lecą nad ZSRR, tymczasem tu tumany pyłu w powietrzu. Żeby coś zobaczyć, lecą niżej, patrzą i widzą olbrzymi transparent: „Pięciolatka w trzy dni” [ZW, s. 12-13].

O nośności tego schematu świadczy również przenoszenie go w różnych wariantach do literatury. W dramacie Janusza Głowackiego Antygona w Nowym Jorku, trawestującym tragedię Sofoklesa, pojawia się trójka bezdomnych emigrantów: Rosjanin (pochodzenia żydowskiego), Portorykanka (współczesne wcielenie Antygony) i Polak ${ }^{19}$.

Stopniowanie trzech (czasem też dwóch albo czterech) konfrontowanych ze sobą postaw może dotyczyć również całych krajów albo ich przywódców, np.: Kennedy - Chruszczow - Gomulka albo Reagan - Breżniew - Jaruzelski. A odpowiedniki takich gradacji znajdziemy w humorze innych państw dawnego bloku wschodniego; na przykład na Białorusi bohaterami są: Clinton - Jelcyn (albo Putin) - Łukaszenka ${ }^{20}$.

Pośród kawałów „międzynarodowych” funkcjonują również serie wyraźnie promujące lub dyskryminujące tylko jedną wybraną nację. Zanikły dowcipy żydowskie (szmoncesy), które paradoksalnie bywały wykorzystywane również jako antyżydow-

19 Warto jeszcze wskazać przypadek swoistego meta-kawału, który narusza zasadę stałości ról przydzielonych przedstawicielom narodów. Narodził się on w serialu Alternatyu'y 4 Stanisława Barei: oto Balcerek opowiada jeden z tych kawałów, ale musi go zmienić na formę ocenzurowaną przez gospodarza domu Anioła; w wersji tak zdeformowanej ulatuje istota dowcipu: zamiast Niemca występuje tam „Niemiec z RFN” (co niewykształcony Balcerek przekręca na „enerdefen”), a w puencie: „Francuzowi spadły walonki".

${ }^{20}$ Zob. J. Prokopiuk, Folklorystyczny wizerunek Aleksandra Eukaszenki, tł. J. Deszcz, „Literatura Ludowa” 2001, nr 6, s. 37-41. 
skie. Wymarły także dowcipy o skappych Szkotach, a głównymi bohaterami negatywnymi w PRL-u stali się Rosjanie ${ }^{21}$. Ci ostatni z kolei mają serię kawałów dyskryminujących o Czukczach ${ }^{22}$, i chyba każdy naród znajduje sobie w bliższym lub dalszym sąsiedztwie geograficznym jakąś ofiarę, z której wyśmiewa się, by zaspokoić swoją nacjonalistyczną megalomanię.

\section{Krytyka i pokrzepienie (funkcje kawału)}

Zbigniew Raszewski wymienia jako najważniejsze dwie funkcje kawału: polemiczną i piętnującą̧2. Dodajmy jeszcze jedną, występującą chyba najrzadziej: demaskującą. Zastanówmy się jednak jeszcze nad tym, czy zawarta w kawałach politycznych autorefleksja ma moc oczyszczającą jako głos polskiego sumienia (na miarę Słowackiego, Norwida, Żeromskiego i Gombrowicza), a więc czy stanowi dowód polskiego samokrytycyzmu, czy też dokonywana w anegdocie ekspozycja skrajnych cech ma cechy te umacniać? Czy dowcip tego typu wpisuje się w model polskiej literatury „rozdrapywania ran”, czy też przeciwnie - powstaje „ku pokrzepieniu serc”? Wladysław Tocki tak postrzega ten problem we wstępie do swej antologii:

w ciężkich czasach bywały jedyną radością, „dodawały otuchy”, „krzepiły serca". Bo dowcip polityczny pozwalał na chwilę zapomnieć o strachu, ujść nabrzmiałej złości, zakpić sobie z największych tego świata, zwyczajnie się pośmiać. Słowem: oczyszczał, rozładowywał niejedną beczkę społecznego „prochu”. $Z$ tej roli komizmu politycznego, dostrzeganych przez uczonych w piśmie i zwyczajnych zjadaczy chleba, można dziś wysnuć tezę: mądra władza, zamiast tysięcy kapusiów, prowokatorów, ubeków, esbeków, sprzedajnych prokuratorów i sędziów, zatrudnić powinna setkę wicmanów, zmusić ich do myślenia, urządzić współzawodnictwo, spisywać skrzętnie wytwory ich diabelskiego chichotu i natychmiast pchać w teren kolporterów śmiechu. Władza taka byłaby mądra, ale zarazem cyniczna. Zdradzam ten koncept tylko dlatego, że wierzę, iż nad Wisłą władza będzie tylko mądra, [...] więc nikt go nie wykorzysta ${ }^{24}$.

Jan Prokopiuk z kolei bardziej patetycznie puentuje swój przegląd białoruskiego humoru ludowego o prezydencie Aleksandrze Eukaszence:

${ }^{21}$ Zob. Z. Raszewski, Wstęp do teorii kawału, op. cit., s. 7.

${ }_{22}$ Zob. A. Jackowski, Folklor kontestacji, op. cit., s. 13.

${ }^{23}$ Zob. Z. Raszewski, Wstęp do teorii kawatu, op. cit., s. 8.

${ }^{24}$ W. Tocki, Dobry żart..., op. cit., s. 4. 
Twórczość tego rodzaju jest też formą walki politycznej z istniejącym systemem politycznym i jej głównym kreatorem. Obnażanie i wyśmiewanie negatywnych cech dyktatora jest także wypadkową nastrojów społecznych, miernikiem świadomości narodowej i politycznej dojrzałości ludzi ${ }^{25}$.

Patriotyczne nastawienie autora usprawiedliwia widoczną tu idealizację zjawiska. $\mathrm{Z}$ pewnością jednak ma rację, jeśli chodzi o ksztaltowanie nastrojów społecznych. Można dodać nawet, że obecny przykład Białorusi, podobnie jak przykłady z peerelowskiej przeszłości Polski, powinny pouczać rozmaite ośrodki badania opinii publicznej, iż badanie krążących dowcipów czasem więcej mówi o społecznych poglądach i nastrojach niż najbardziej rozbudowane ankiety. Jednak, o czym już wspominałem, opozycyjna wspólnota komunikacyjna, funkcjonująca w prostym układzie w systemie totalitarnym, w warunkach demokracji rozpada się na mniejsze kręgi okazjonalne i efemeryczne, toteż nie mogłaby już służyć za barometr nastrojów społeczeństwa.

Niektórzy badacze folkloru wykazują tu jednak skłonność do przesady — zwłaszcza w sytuacjach wyjątkowych, które narzucają im potrzebę okolicznościowej żarliwej deklaracji politycznej w miejsce racjonalnego dystansu naukowca. Tak sformulowane cele wydają się przecież ideałami satyry socrealistycznej à rebours. Przypomnijmy: 8 listopada 1948 roku odbył się w Warszawie zorganizowany z inicjatywy „Szpilek” I Ogólnopolski Kongres Satyryków, na którym Jerzy Borejsza w referacie programowym zdefiniowal publicystyczne i polityczne zadania satyry w Polsce Ludowej. Satyra powinna:

1) prezentować rzeczywistość w sposób odpowiadający założeniom walki klasowej oraz operować figurą wroga; 2) zajmować postawę krytyczno-moralizatorską i być uwrażliwiona na szkodliwe zjawiska społeczno-polityczne; 3) podejmować aktualną tematykę, odnoszącą się do wyrazistych realiów historycznego „tu i teraz”; 4) wykraczać poza sferę literatury $[\ldots]^{26}$.

Socrealistyczny model satyry w słuzbie wladzy, przeniesiony mechanicznie (i zapewne nieświadomie) na służbę opozycji jako narzędzie walki z władzą, jest zaledwie wzniosłym postulatem zaangażowanych politycznie autorów opracowań, którzy zatracili badawczy krytycyzm i nie znajduje potwierdzenia w konfrontacji z przykładami. Dotyczy to nie tylko przypadku Białorusi. Violetta Krawczyk-Wasilewska w taki oto sposób spuentowała swój przegląd świeżych wówczas dowcipów o ataku terrorystycznym na Stany Zjednoczone 11 września 2001 roku:

${ }^{25}$ J. Prokopiuk, Folklorystyczny wizerunek Aleksandra Łukaszenki, op. cit., s. 47.

${ }^{26}$ K. Alichnowicz, „Miejsce dla kpiarza”. Dyskusja o satyrze przed rokiem 1949, w: Presja i ekspresja. Zjazd szczeciński i socrealizm, red. D. Dąbrowska, P. Michałowski, Szczecin 2002, s. 50. 
ustny, pisany $\mathrm{i}$ wizualny folklor związany tematycznie $\mathrm{z}$ terroryzmem jako problemem globalnym pełni trzy podstawowe funkcje: poznawczą - ukazującą osobliwość zjawiska terroryzmu, ostrzegającą - informującą o zagrożeniu oraz terapeutyczną, oswajającą - poprzez makabryczny humor - zjawisko terroryzmu, z którym społeczeństwu przyszło żyć w XXI wieku ${ }^{27}$.

Taka apoteoza budzi jednak wątpliwości, i to poważne - choć sama wydaje się niepoważna, a nawet może być uznana za dowcip, tym razem już nie polityczny, ale naukowy. Choćby dlatego, że pośród wyliczonych funkcji zabrakło najważniejszej, a zarazem jedynej niepodważalnej: ludycznej. Natomiast, co do funkcji „poznawczej” czy „ostrzegającej”, nie można się zgodzić. Przypisywanie humorowi tak doniosłej funkcji pedagogicznej i edukacyjnej, realizującej oświeceniowe hasło „uczyć - bawiąc", wydaje się interpretacją naiwną. Rozumując analogicznie, to tak, jakby twierdzić, ze czarny humor o seryjnych mordercach i sadystach miał wzbudzać empatię i czujność społeczeństwa, a dowcipy o Kubie Rozpruwaczu mogły zastępować jeśli nie poradniki pierwszej pomocy, to kurs chirurgii dla amatorów. Czyżby humor miał służyć za źródło informacji - a więc „zwierciadło” wcale nie „krzywe”? Oczywiście są takie rzadkie sytuacje, gdy anegdota jako alternatywne źródło służy za „przeciek” i przemyca wiadomości nieoficjalne, pozostające $w$ opozycji do propagandy w danej chwili dominującej w mediach. W przypadku wydarzeń z 11 września tak się jednak nie stało, bo przecieki od początku pochodziły z mediów informacyjnych: najpierw o szkoleniu talibów i arabskich pilotów-terrorystów przez USA, o słabości systemu obrony powietrznej supermocarstwa, a po paru latach także o kompromitującej nieskuteczności poszukiwań Osamy bin Ladena w zrównanym z ziemią Afganistanie, wreszcie - o braku uzasadnienia interwencji w Iraku, który ani nie dysponował bronią masowego rażenia, ani nie mial związku z poszukiwanym przywódcą terrorystów. Kompromitacja polityków nastąiła poza sferą humoru, a światowe oszustwo, choć wywołało samobójstwo jednego z ekspertów brytyjskich, nie spowodowało nawet dymisji najwyższych władz w Ameryce, Wielkiej Brytanii ani w Polsce, gdzie nieopatrznie sam prezydent Kwaśniewski przyznał, iz „byliśmy zwodzeni” (co zresztą natychmiast pokrętnie i bojaźliwie odwołał).

Humor częściej natomiast przyczynia się do kształtowania społecznego nastawienia wobec faktów i osób, steruje akceptacją lub odrzuceniem politycznych zdarzeń i decyzji polityków. Dziwne, że autorka w analizowanym przez siebie materiale nie dostrzegła, iż w grupie omawianych przez siebie kawałów o 11 września można wy-

27 V. Krawczyk-Wasilewska, Po 11 urześnia, czyli folklor polityczny jako wyraz globalnego lęku, „Literatura Ludowa” 2003 nr 3, s. 35. 
dzielić dwie opcje, powiedzmy: „antyarabską” i „antyamerykańską”, a zatem - mimo zgodnego potępienia aktów terroru i zjawiska terroryzmu przez społeczeństwa Europy i większości świata, ujawnil się wyraźny rozłam poglądów. Uwidoczniło się to choćby przed interwencją w Afganistanie, a potem w Iraku, kiedy to przewaga internautów i obywateli RP opowiedziała się przeciw polskiemu udziałowi w inwazji i okupacji, nazwanej oficjalnie „misją stabilizacyjną” - co zignorował ówczesny prezydent Aleksander Kwaśniewski, wysyłając tam Wojsko Polskie.

Łatwiej można się zgodzić na funkcję „terapeutyczną” kawału politycznego. Śmiech oswaja to, co straszne - i to rozpoznanie znajduje potwierdzenie w badaniach psychologicznych. Poza tym pozwala tylko umilać czas oraz integrować towarzysko. Jeśli natomiast na przykład w tym dowcipie ktoś potrafi wskazać walory edukacyjne i ostrzegawcze, dowiedzie nie tyle swej badawczej przenikliwości, co poczucia humoru:

Stoi dwóch ludzi na 98 piętrze. Jeden pyta drugiego: - Pan czeka na windę czy na samolot?

albo

Przychodzi Arab na lotnisko i mówi: - Poproszę bilet do NYC [New York City]. Na to kasjerka: - A na które piętro pan sobie życzy?28

\section{Adaptacje i transfery (kawały wędrowne)}

W humorze politycznym PRL-u dominuje kawał rodzimy, jakkolwiek znane są również kawały z importu, a do głównych źródeł należy autentyczny dowcip ormiański, z którego pochodzi wspomniana już słynna seria o Radiu Erewañ ${ }^{29}$. Dostrzec można jednak różne procesy adaptacji dowcipów przez aktualizowanie realiów, a więc transfery dokonywane między epokami i krajami. Niektóre anegdoty o rządach Władysława Gomulki po wymianie nazwisk i tła fabularnego zostały reaktywowane jako dowcipy o rządach Edwarda Gierka. Można więc zaobserwować także transfery wewnątrzkrajowe. Jeśli chodzi o temat najbardziej uniwersalny, jaki stanowi głupota, znajdziemy go jako motyw wędrowny w różnych seriach kawałów: najpierw o wariatach, potem o milicjantach, a w warunkach demokracji — jako przejaw nietolerancji w dowcipach o blondynkach. Glupota pasuje też do wielu przywódców państw i partii, toteż łatwo ich obsadzić w każdej z wypróbowanych fabuł uniwersalnej serii, stosownie do społecznego zapotrzebowania. Poznając dowcipy zagraniczne, zauważamy w nich wiele

${ }^{28}$ Cyt. za: ibidem, s. 30.

29 Zob. Z. Raszewski, Wstęp do teorii kau'ału, op. cit., s. 5. 
podobieństw, ale zarazem różnic, które ograniczają ich tłumaczenie i przepływ międzynarodowy ${ }^{30}$.

Kiedy w zestawie kawałów z lat pięćdziesiątych PRL-u znajdujemy anegdoty o kulisach Kremla, zwłaszcza najstarsze, o nieżyjącym już Leninie lub żyjącym wtedy Stalinie, albo o zagranicznych ośrodkach władzy, domyślamy się, że nie zostały wymyślone w Polsce, ale przywędrowały na przykład ze Wschodu, w ślad za Armią Czerwoną, razem z importowaną władzą komunistyczną. Nie znaczy to jednak, że Polska była wyłącznie importerem dowcipów; również je eksportowała, na co znajdziemy dowody. Transfery dokonują się do krajów sąsiednich, o podobnych doświadczeniach historycznych, społecznych, gospodarczych i politycznych, na przykład byłych krajów bloku wschodniego. Dowcipy PRL-u, poddane odpowiedniej obróbce, znajdują zastosowanie w państwach, które transformacji ustrojowej dotąd nie przeszły. Oto przykład, w którym „chirurgiczny” kawał o prezydencie Białorusi Łukaszence wydaje się dziwnie znajomy, ponieważ jest przekształceniem wcześniejszej polskiej wersji:

Podczas międzynarodowego kongresu chirurgów występuje Niemiec: „Na poboczu znaleźliśmy rękę, przyszyliśmy facetowi i ten został superwydajnym robotnikiem”. Na to Rosjanin: „My znaleźliśmy nogi, przyszyliśmy inwalidzie, a ten został mistrzem świata w biegu na $60 \mathrm{~m}$ ”. Dalej Amerykanin: „My znaleźliśmy głowę, przyszyliśmy trupowi i ten został laureatem nagrody Nobla”. Przyszła kolej na Białorusina: „W lasach mohylewskich znaleźliśmy dupę. Doszyliśmy wąsy i tak uzyskaliśmy prezydenta" ${ }^{31}$.

Wielu z nas pamięta, że wcześniej, w latach osiemdziesiątych (choć trudno w folklorze przyjąć, że znaczy to również „pierwotnie”) obiegła nasz kraj podobna historyjka o Jerzym Urbanie i miała nieco inne zakończenie - z polskim chirurgiem, który, gdy na miejscu wypadku „znaleziono tylko dupę i uszy”, zszył je ze sobą i „pacjent dziś jest rzecznikiem prasowym rządu".

Obok transferów międzynarodowych obserwujemy dziś także zjawisko „globalizacji” kawału — dotyczące zarówno jego tematyki, jak i obiegu. Światowy zasięg polityki sprawił. że dowcip o tematyce politycznej zyskał charakter międzynarodowy, gdyż coraz częściej dotyczy walki supermocarstw i sprzymierzonych krajów demokracji $\mathrm{z}$ ustrojami totalitarnymi albo światowym terroryzmem. Dowodzą tego wspomniane już dowcipy o zamachu na WTC 11 września 2001 roku. Jednocześnie obserwujemy,

\footnotetext{
${ }^{30}$ Cenną publikacją na ten temat jest Humor europejski, red. M. Abramowicz, D. Bertrand, T. Stróżyński, Lublin 1994.

${ }^{31}$ Cyt. za: J. Prokopiuk, Folklorystyczny wizerunek Aleksandra Eukaszenki, op. cit. , s. 43.
} 
że zmienia się obieg i metody rozpowszechniania kawału, co dokonuje się to głównie za sprawą Internetu, poczty e-mailowej oraz sieci telefonii komórkowych ${ }^{32}$.

Zjawisko kawału drukowanego, choć ma niewątpliwie proweniencję folklorystyczną i znaczenia obiegu ustnego nie likwiduje, a nawet go wspomaga, dziś stanowi po prostu jeden z ubocznych nurtów literatury popularnej. Elektroniczne metody rozpowszechniania humoru (głównie przez dzieci i młodzież) nie zlikwidowały tradycyjnego towarzyskiego obiegu, ale wydatnie go wspomagają. Wydaje się, że w tym wypadku zmiana nośnika nie ma charakteru jakościowego i nie narusza specyfiki folkloru.

Jeśli kawał polityczny obecnie zanika w obiegu folklorystycznym, dzieje się to za sprawą nie internetowej globalizacji, lecz jego demokratycznej legalizacji, a w efekcie również instytucjonalizacji, gdyż stał się domeną wyspecjalizowanych kabaretów, szopek, programów rozrywkowych w radiu i telewizji, które jednak, wykorzystując bezcenzuralną wolność słowa, tracą często finezję konieczną w minionej epoce aluzji i języka ezopowego. Puentą niech więc będzie charakterystyczna dla każdego kawału „zgodna niezgodność” oceny zagłady gatunku: stało się tak i „niestety”, i „na szczęście".

32 Zob. V. Krawczyk-Wasilewska, Po 11 września..., op. cit., s. 25-34. 